\title{
てこ式変位拡大機構を用いた粘弾性一摩擦複合ダンパの研究*
}

\author{
松 岡 太 一 ${ }^{* 1}$, 大亦 絢一郎*2, 宮 城 善一*2
}

\section{A Study of a Viscoelastic-Friction Damper Using a Lever-Type Displacement Magnifying Mechanism}

\author{
Taichi MATSUOKA*3, Kenichiro OHMATA and Zenichi MIYAGI \\ ${ }^{* 3}$ Department of Mechanical Engineering Informatics, Meiji University, \\ 1-1-1 Higashimita, Tama-ku, Kawasaki-shi, Kanagawa, 214-8571 Japan
}

\begin{abstract}
In the previous paper, the authors proposed a new type of magnetic damper using a lever-type displacement magnifying mechanism and rare-earth magnets. In this paper, a viscoelastic-friction damper and a viscoelastic damper using the lever-type displacement magnifying mechanism and viscoelastic material are proposed in order to obtain a passive damper which gives damping and stiffness within a relative displacement in the region of about $0.1 \sim 20 \mathrm{~mm}$. Denoting the magnifying ratio by $\lambda$, the damping force and the spring force of the viscoelastic material are increased $\lambda^{2}$ times and the friction force is increased $\lambda$ times by the magnifying mechanism. The trial dampers were made and the resisting force characteristics were measured. To describe the mathematical properties of the viscoelastic material, a four-element viscoelastic model was used, and the parameters of the model were identified using the experimental results. The frequency responses and the seismic responses of a three-dimensional piping system supported by each damper were measured using an electrohydraulic type shaking table. The experimental results are compared with the calculated results obtained by the finite element method (ANSYS), and the effects of vibration suppression of the dampers are discussed.
\end{abstract}

Key Words: Damper, Viscoelastic-Friction Damper, Viscoelastic Damper, Damping Material, Displacement Magnifying Mechanism, Frequency Response, Seismic Response

\section{1.はじめに}

建物の高層化あるいは機器装置の高精度化に伴い, 大振幅振動から微振動に至るまでのさまざまな大きさ の振動を抑制するために各種ダンパが開発されてい る.これらの中で比較的微小な振動をパッシブ制御技 術で抑制するためには，変位や隇衰力の拡大機構が必 要となる場合がある。著者らは以前に $0.1 \mathrm{~mm}$ から $10 \mathrm{~mm}$ 程度までの振幅をもつ振動を対象として, 二 段てこ式変位拡大機構と希土類磁石を用いたパッシブ 型磁気ダンパを開発した(1).この磁気ダンパは，拡大 機構の拡大率の二乗に比例して滅衰力を大きくするこ とができる.一方, 高い減衰性能をもつ粘弾性材料と して, 近年シリコンゲル, 高減衰ゴム, アクリル系粘 弾性材をはじめ各種粘弾性材料が開発され，ダンパに も応用されている(2) (10). また笠井らは，小振幅時で は粘弾性体の粘性と弾性を利用し, 大振幅時では弾塑 性体の塑性変形(または摩擦)を利用する粘弾性一弾塑

* 原稿受付 2002 年 3 月 8 日.

*1 准員, 明治大学大学院理工学研究科( 摩区東三田 1-1-1).

*2 正員, 明治大学理工学部.

E-mail : matsuoka@isc.meiji.ac.jp
性体直列結合ダンパを開発した(11)(12)。これにより， 広い振幅範囲を対象としたダンパにも粘弾性材料を適 用できるようになった。

本研究では, $0.1 \mathrm{~mm}$ から数 $10 \mathrm{~mm}$ 程度までの振 幅範囲の振動を対象として，笠井らのアイディアと二 段てこ式変位拡大機構を組合せた粘弾性一摩擦複合ダ ンパを提案する.このダンパは二段てこ式変位拡大機 構の先端に粘弾性材一摩擦直列結合体を取付けること により，大きな振動時には摩擦力を抎大して大きな抵 抗力を得ようとするものである. アクリル系粘弾性材 料を用いて粘弾性一摩擦複合ダンパ(以下複合ダンパと 略す)を試作し，その抵抗力特性を解析と実験によっ て調べる．また比較の目的で，複合ダンパの摩擦部 (スライド部)を固定した粘弾性材の変形のみを利用す るダンパ(粘弾性ダンパ)も試作して，その抵抗力特性 を調べる. 次に,これら 2 種類のダンパを三次元配管 モデルに取付けて周波数応答実験と解析および地震応 答実験と解析を行い, 両ダンパの制振効果を確かめ る.なお，清水らは粘弾性材の分数階微分による振動 解析(13)(14) を行っているが，本論文では粘弾性材を線 形四要素モデルに置き換えて振動解析を行う。 


\section{2. 粘弾性一摩擦複合ダンパおよび 粘弾性タンパの構造と变位拡大率}

ピン支持てこ式変位拡大機構を用いた粘弾性一摩擦 複合ダンパの構造を図 1 に示す. 本ダンパは，両端の ロッドエンド，ロードコラム，ピン支持された二段て こ式変位拡大機構, プッシュロッド, 直動玉軸受, 基 礎板, 粘弾性材, ブレーキシューおよび摩摖板から構 成されている．図 1 で,ブレーキシューと摩擦板の間 を固定すれば粘弾性ダンパとなる。

両端のロッドエンド間に相対変位 $x$ を与えると, 拡 大機構によって基礎板の変位が拡大される。この拡大 された変位 $x_{r}$ は, 図 2 の幾何学的な関係から, 次式 で与えられる。

$$
x_{r}=(c+d) \sin \theta_{4}-g\left(1-\cos \theta_{5}\right)
$$

ここで,

$$
\theta_{4}=\sin ^{-1}\left(\frac{x_{p}}{c}\right), \theta_{5}=\sin ^{-1}\left(\frac{(c+d)\left(1-\cos \theta_{4}\right)}{g}\right)
$$

$x_{p}$ は点 6 の上下方向変位を表し, 斜辺の長さ $f$, 傾斜 角 $\theta_{3}$ の直角三角形に対するピタゴラスの定理より求 まる。すなわち

$$
\begin{gathered}
{\left[a+b+c-\left\{(a+b) \cos \theta_{1}+c \cos \theta_{4}\right\}\right]^{2}} \\
+\left[x_{p}+f-(a+b) \sin \theta_{1}\right]^{2}=f^{2}
\end{gathered}
$$

Table 1 Physical condition of the trail damper

\begin{tabular}{llll}
\hline \multirow{4}{*}{ Lever } & Length & $a, b$ & $20,40 \mathrm{~mm}$ \\
& Length & $c, d$ & $20,40 \mathrm{~mm}$ \\
& Length & $e, f$ & $30,50 \mathrm{~mm}$ \\
& Length & $g$ & $30 \mathrm{~mm}$ \\
\hline \multirow{4}{*}{ VEM. } & Material & & $3 \mathrm{M} \mathrm{ISD112}$ \\
& Length & $20 \mathrm{~mm}$ \\
& Width & $20 \mathrm{~mm}$ \\
& Thickness & \multicolumn{2}{c}{$10 \mathrm{~mm}$} \\
& Number & \multicolumn{2}{c}{ 1 layer (Compound damper) } \\
\hline Friction & Force & \multicolumn{2}{c}{5 layers (VEM damper) } \\
\hline
\end{tabular}

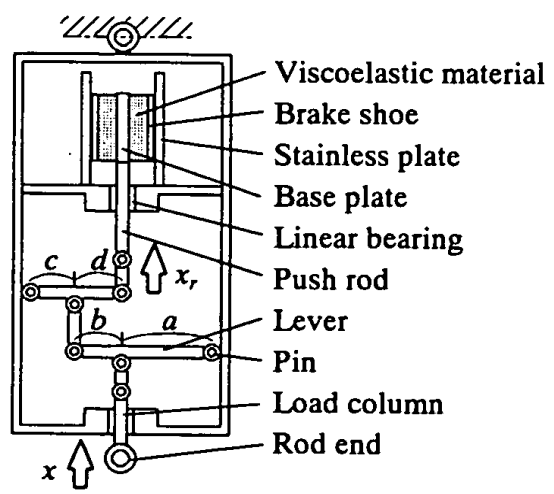

Fig. 1 Conceptual sketch of the compound damper
上式を $x_{p}$ について解くと

$$
x_{p}=\frac{R S+\sqrt{(R S)^{2}-\left(Q^{2}+R^{2}\right)\left(S^{2}-4 Q^{2} c^{2}\right)}}{2\left(Q^{2}+R^{2}\right)}
$$

ただし

$$
\left\{\begin{array}{l}
Q=a+b+c-(a+b) \cos \theta_{1} \\
R=(a+b) \sin \theta_{1}-f \\
S=c^{2}-f^{2}+Q^{2}+R^{2}
\end{array}\right.
$$

式（4)において，的は次式の関係から求まる.

$$
x=e+a \sin \theta_{1}-\sqrt{e^{2}-a^{2}\left(1-\cos \theta_{1}\right)^{2}}
$$

また， $x$ は微小と考え，てこ比を用いて㹡大率を表す と

$$
\lambda=\frac{(a+b)(c+d)}{a c}
$$

式(1)〜（5)を用いて，表 1 に示すようなてこ比をも つ拡大機構の $x$ と $x_{r}$ の関係を計算すると, 図 3 の実 線のようになる. 図 3 からわかるように, $x= \pm 3 \mathrm{~mm}$ 程度までは $x$ と $x_{r}$ の関係はほほ直線的となり，拡大 率は約 $\lambda=8.8$ となる [式( 6 ) から求めた拡大率は $\lambda$ $=9$ となる]. したがって拡大された変位 $x$, 速度 $v_{r}$ は次式のように表される.

$$
x_{r}=\lambda x, v_{r}=\lambda v
$$

ここで, $v$ はダンパ下端の入力速度を表す。

最初に, 複合ダンパの粘弾性材の抵抗力が摩擦力よ

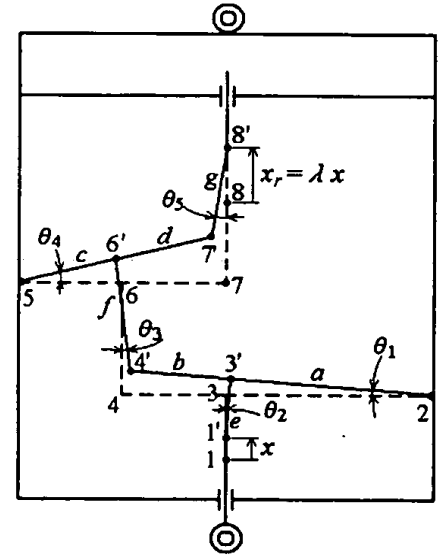

Fig. 2 Analytical model of the magnifying mechanism

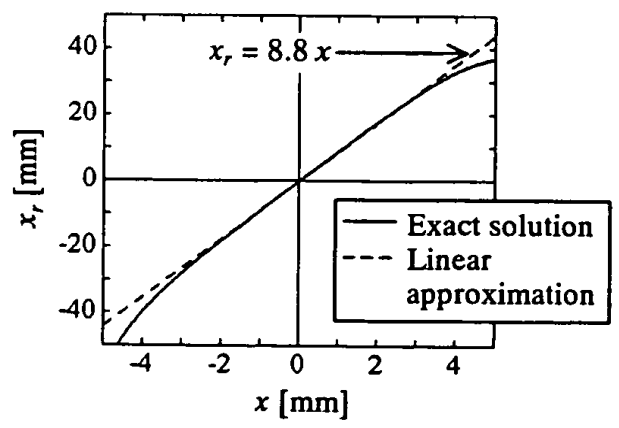

Fig. 3 Calculated results for magnifying displacement 
りも小さい範囲を考える。この範囲では, 複合ダンパ は粘弾性ダンパとしての特性をもつことになる。ダン パの両端のロットエンド間に相対変位 $x$ を与えると, 基礎板に貼付けた粘弾性材がせん断変形することによ って, 拡大された変位, 速度に比例した抵抗力が生じ る.この抵抗力 $F$ は一般的に周波数依存性のほかに, 振幅依存性および温度依存性をもつが, 本研究におい ては振動対象を地震時の振動および $20 \mathrm{~Hz}$ 程度まで の周波数範囲の振動に限ることにし, 温度依存性は考 虑しない.ここで粘弾性材の動的特性を図 4(a)に示 すような Maxwell モデルとVoigt モデルを並列に並 ベたモデルで近似すると，このモデルの等価ばね定数 $k_{e q}$ と等価粘性減衰係数 $c_{e q}$ は次式で与えられる.

$$
\begin{aligned}
& k_{e q}=\frac{S}{l}\left(\gamma_{1}+\gamma_{2} \frac{\omega^{2} \tau_{2}^{2}}{1+\omega^{2} \tau_{2}^{2}}\right) \\
& c_{e q}=\frac{S}{l}\left(\eta_{1}+\eta_{2} \frac{1}{1+\omega^{2} \tau_{2}^{2}}\right)
\end{aligned}
$$

ここで， $\gamma_{1}, \gamma_{2}$ はばね要素 1,2 の剛性率, $\eta_{1}, \eta_{2}$ はダッ シュポット 1,2 の粘性率, $\tau_{2}=\eta_{2} / \gamma_{2}$ はダッシュポッ ト 2 の応力緩和時間を表し, $S, l$ は粘弾性体の断面積 と厚さを表す.この場合のダンパの全抵抗力 $F$ は次 式で与えられる。

$$
F=k_{e q} \lambda^{2} x+c_{e q} \lambda^{2} \dot{x}
$$

次に, 粘弾性材の抵抗力が摩擦力に等しくなり, 摩擦 部が相対運動を行う場合を考えると,ダンパの抵抗力 は次式のようになる。

$$
F=\lambda f_{0}
$$

ここで, $f_{0}$ は摩擦部のクーロン摩擦力を示す.また, 摩擦部を固定した粘弾性ダンパの抵抗力は, すべての 振幅・振動数において式(9)で与えられる. 式(9)， (10)からわかるように，等価ばね力および等価減衰力 は $\lambda^{2} に$, 摩摖力は $\lambda に$ 比例するので, $\lambda$ をきくする ほど抵抗力が大きくなる。

\section{3. 抵抗力特性}

$3 \cdot 1$ 試作したダンパの構造＼cjkstart試作した複合ダン パの構造を図 5 に示し, その諸元を表 1 に示す. 粘弾

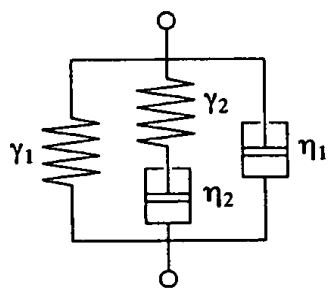

(a) VEM damper

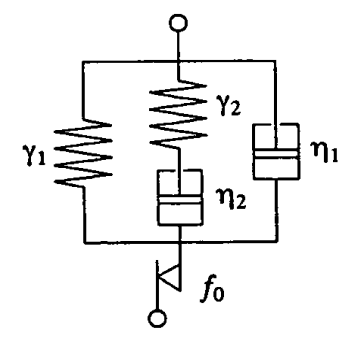

(b) Compound damper
Fig. 4 Equivalent models of the dampers
性材は, 長さ $20 \times$ 幅 $20 \times$ 厚さ $10 \mathrm{~mm}$ のアクリル系 粘弾性材（3M ISD 112）であり，一方を基礎板に貼付 け，他方をカーボン製ブレーキシューに貼付けた。ブ レーキシューと容器側壁のステンレス板が相対変位す ることにより滑らかなクーロン摩擦力が得られる. ま た,この複合ダンパのブレーキシューを容器側壁に固 定して, 粘弾性材の変形のみを利用する粘弾性ダンパ を試作した。粘弾性ダンパには，5枚の粘弾性材を積 層にして用いた。この際各層の粘弾性材がせん断方向 にのみ変形するように, 各粘弾性材をガイドプレート (溝に沿って上下に移動する板)で挟んで積層にしてあ る.

$3 \cdot 2$ 粘弾性タンパの抵抗力測定 最初に, 粘弾 性ダンパの抵抗力特性を調べた. 図 6 に示すように, 粘弾性ダンパの一端を振動台に, 他端をロードセルを 介して固定壁に取付け，振幅を 4 種類 $(0.5,1.0,2.0$, $3.0 \mathrm{~mm})$ に変化させた場合について, 振動台に周波数 1 4 Hz の正弦波状変位を与えて変位と抵抗力の履歷 曲線を求めた。振動台の変位の測定にはインダクタン ス型変位計を用いた。

粘弾性ダンパの抵抗力実験結果を計算結果と併せて 図 7 に示す. 図 7 の実験結果と式 (8) を用いて試行錯 誤により四要素モデルのパラメータを同定すると, 表 2 のようになる，表 2 の值は，まず粘弾性体をVoigt モデルで近似して抵抗力の履歴曲線より $\gamma_{1}, \eta_{1}$ の初期 值を求め， $\gamma_{2}, \eta_{2}$ はそれぞれ $\gamma_{1}, \eta_{1}$ の数分の一から数 倍の值であると仮定して, これら四つのパラメータを 少しずつ変えて同定した值である，これらの同定され た值は，拡大された変位と速度の元で同定されてい る。また, 実験から得られた貯蔵せん断弹性係数 $G^{\prime}$ および損失せん断弾性係数 $G^{\prime \prime}$ を $r=1 / 2$ の分数階微 分Voigt モデルを用いて求めた值と併せて図 8 に示 す.ここで, $G^{\prime}, G^{\prime \prime}$ と $k_{e q}, c_{e q}$ の間には次の関係があ

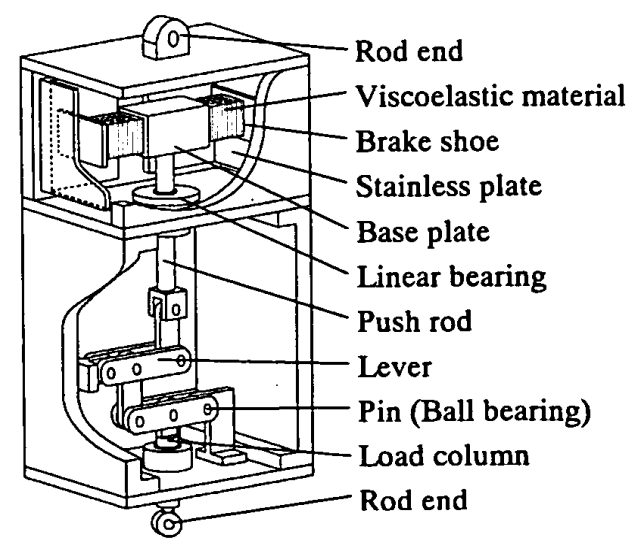

Fig. 5 Construction of the compound damper 
Table 2 Parameters of the 4-element model

\begin{tabular}{ccc}
\hline \multirow{2}{*}{ Stiffness rate } & $\gamma_{1}$ & $1.265 \times 10^{5} \mathrm{~N} / \mathrm{m}^{2}$ \\
& $\gamma_{2}$ & $0.493 \times 10^{5} \mathrm{~N} / \mathrm{m}^{2}$ \\
\hline \multirow{2}{*}{ Damping rate } & $\eta_{1}$ & $2.466 \times 10^{3} \mathrm{Ns} / \mathrm{m}^{2}$ \\
& $\eta_{2}$ & $5.261 \times 10^{3} \mathrm{Ns} / \mathrm{m}^{2}$ \\
\hline
\end{tabular}

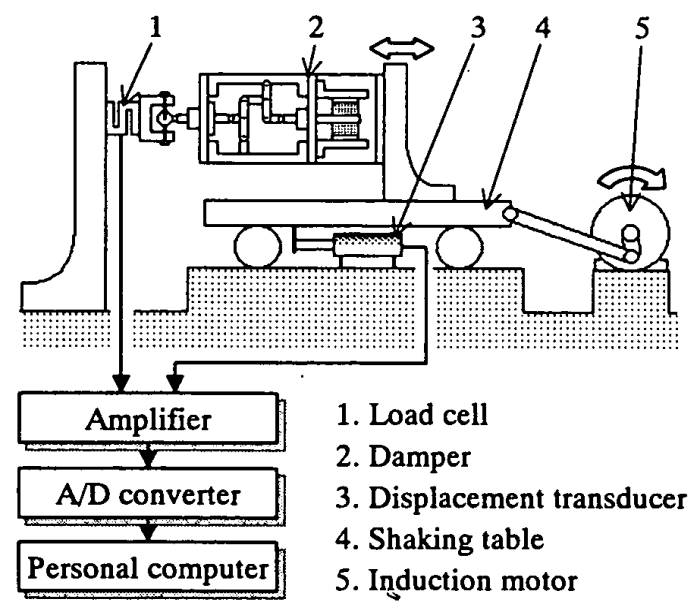

Fig. 6 Experimental apparatus
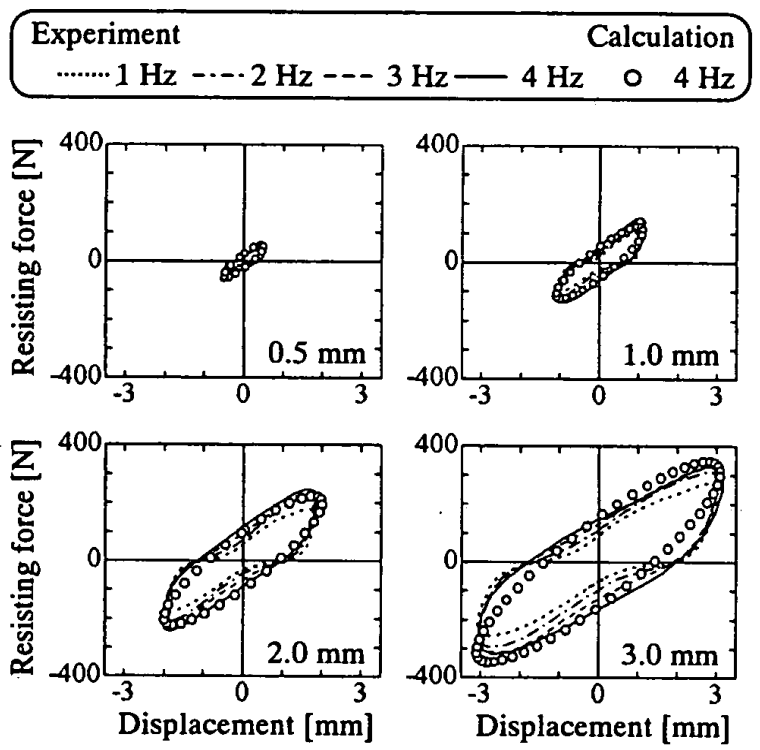

Fig. 7 Resisting force characteristics of the VEM damper

る.

$$
k_{e q}=G^{\prime}(S / l), c_{e q}=G^{\prime \prime}(S / \omega l)
$$

図 8 より, 0.5 $10 \mathrm{~Hz}$ 程度までは四要素モデルおよ び分数階微分 Voigt モデルによる計算値と実験值は かなり一致しており, 図 4 に示した四要素モデルで近 似できることがわかる。

$3 \cdot 3$ 複合ダンパの抵抗力測定 次に, 粘弾性ダ ンパの場合と同様にして, 試作した粘弾性-摩擦複合 ダンパの抵抗力を測定した. 実験結果を計算結果と併

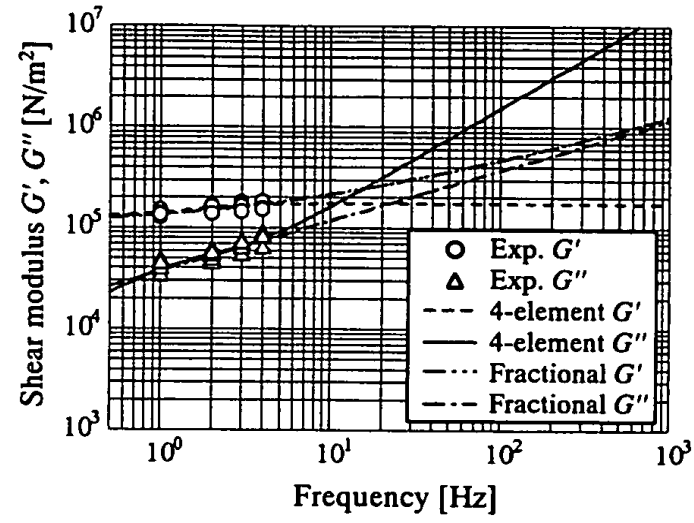

Fig. 8 Shear storage modulus and loss modulus of the viscoelastic material

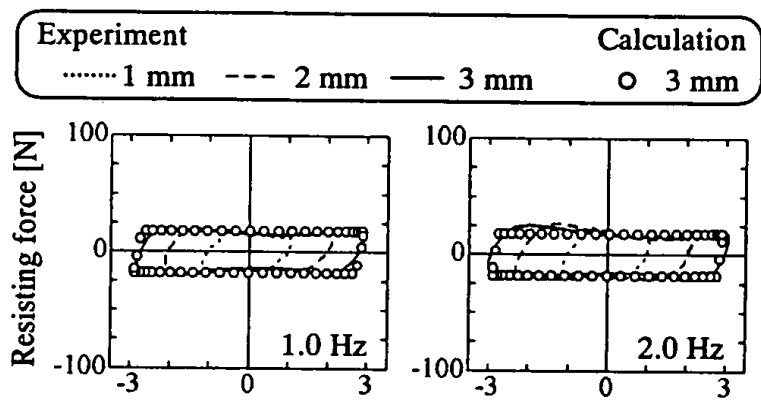

(a) In the case of $f_{0}=2.1 \mathrm{~N}$
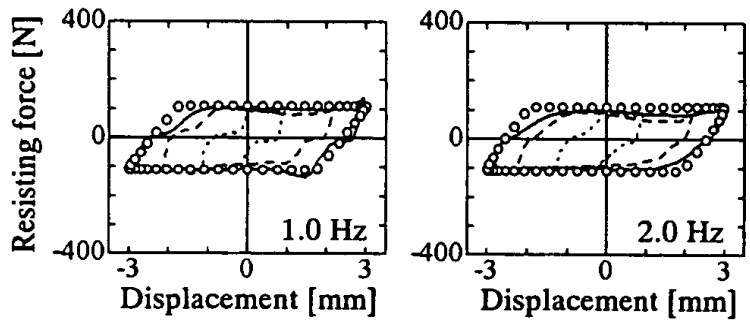

(b) In the case of $f_{0}=12.5 \mathrm{~N}$

Fig. 9 Resisting force characteristics of the compound damper

せて図 9 に示す. 図 9 から, 複合ダンパは完全弾塑性 型の弾塑性ダンパ的な抵抗力特性を示すことがわか る.

\section{4. ダンパで支持された三次元配管モテルの 振動実験と解析}

4・1 運動方程式 プラント用配管を想定した三 次元配管モデルの屈曲部に本複合ダンパおよび粘弾性 ダンパが取付けられている場合について，床に上下方 向の正弦波状変位または実地震波が作用したときの配 管の周波数応答解析および地震応答解析を行った。解 析モデルを図 10 に示す. 配管を $n$ 個の微小長さ要素 に分割し，配管屈曲部の位置を $i$ 番めとすると，床が 上下方向に絶対加速度 $\ddot{z}$ を受けたときの運動方程式 は次式で示される。 
$[M]\{\ddot{u}\}+[A]^{-1}\{u\}+\gamma[A]^{-1}\{\dot{u}\}+\{F\}$

$=-[M]\{\ddot{z}\}$

ここで, $[M]$ は質量マトリックス, $[A]$ は影響係数マ トリックス, $\{u\}(=\{y\}-\{z\})$ は配管の相対変位べク トル, $\{\ddot{z}\}$ は入力加速度ベクトル, $\{F\}$ は抵抗力ベク トルを表し，それぞれ次式で与えられる。

$$
\begin{gathered}
\{u\}=\left\{u_{1}, \cdots, u_{n}\right\}^{T},\{y\}=\left\{y_{1}, \cdots, y_{n}\right\}^{T}, \\
\{\ddot{z}\}=\{\ddot{z}, \cdots, \ddot{z}\}^{T}
\end{gathered}
$$$$
[A]=\left[\begin{array}{ccc}
A_{11} & \cdots & A_{1 n} \\
\vdots & & \vdots \\
A_{n 1} & \cdots & A_{n n}
\end{array}\right]
$$

$$
[M]=\left[\begin{array}{ccccc}
m_{1} & & & & 0 \\
& \ddots & & & \\
& & m_{i}+m_{d} & & \\
& & & \ddots & \\
0 & & & & m_{n}
\end{array}\right],\{F\}=\left\{\begin{array}{c}
0 \\
\vdots \\
f_{i} \\
\vdots \\
0
\end{array}\right\}
$$

ここで, $f_{i}$ はダンパの抵抗力を表し, 式( 8$)$ （10)で 与えられる.また $m_{d}$ はダンパ可動部の等価質量を表 す. 数值計算に際しては, 配管を 225 個の微小長さ要 素に分割し，配管屈曲部に図 4 の四要素モデルが取付 けられているものとして計算を行った。計算值は，有 限要素法プログラム(ANSYS)を用い, ニュートンラ プソン法による非線形時刻歴応答解析により求めた。

$4 \cdot 2$ 周波数応答実験 試作した 2 種類のダンパ （複合ダンパ，粘弾性ダンパ）を長さ $1.5 \times 1.5 \mathrm{~m}$, 高 さ $1.5 \mathrm{~m}$, 直径 $41.3 \mathrm{~mm}$, 肉厚 $1.5 \mathrm{~mm}$ の三次元配管 モデルの屈曲部に取付け，電気油圧式振動台により配 管基礎部に 0 10 Hz の正弦波状上下変位を与えて配 管屈曲部の相対変位を測定した。実験に用いた三次元 配管モデルの諸元を表 3 に示す. 配管の内部減衰比 $\gamma$ は, 配管屈曲部を上下方向にインパルス加振して, 一 次の固有振動モードの応答波形より求めた実験値であ る. 配管屈曲部の相対変位(たわみ)はインダクタンス 型変位計で測定し, $\mathrm{A} / \mathrm{D}$ 変換してパーソナルコンピ ュータに取込んだ。

実験結果を計算結果と比べて図 11 に示す。図 11 よ りわかるように，一次共振点における配管屈曲部のた わみはダンパなしの場合に比べて, 複合ダンパ $\left(f_{0}=\right.$ $2.1 \mathrm{~N})$ 取付時で $1 / 6$ 程度, 粘弾性ダンパを取付けた 場合は $1 / 4$ 程度に低隇する。

$4 \cdot 3$ 実地震波応答実験 本複合ダンパおよび粘 弾性ダンパの配管用耐震装置としての有効性を確かめ るために, 2 種類のダンパを三次元配管モデルの属曲 部に取付け，地震応答実験と解析を行った。

実験に用いた地震波は最大加速度 $3 \mathrm{~m} / \mathrm{s}^{2}$ に基準化
Table 3 Experimental condition of the three-dimensional piping

\begin{tabular}{lll}
\hline Material & & C1100BE \\
Length of straight parts & $L$ & $1.5 \mathrm{~m}$ \\
Outside diameter & $d$ & $41.3 \mathrm{~mm}$ \\
Wall thickness & $w$ & $1.5 \mathrm{~mm}$ \\
Young's modulus & $E$ & $110 \mathrm{GPa}$ \\
Density & $\mu$ & $8500 \mathrm{~kg} / \mathrm{m}^{3}$ \\
Internal damping ratio & $\gamma$ & 0.003 \\
\hline
\end{tabular}

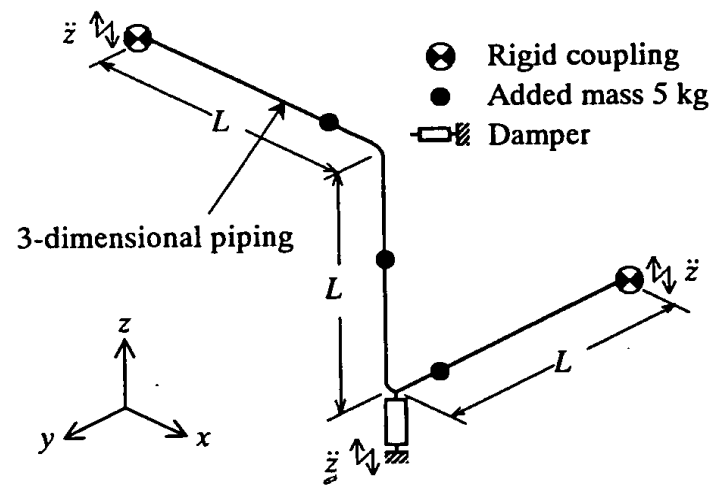

Fig. 10 Analytical model

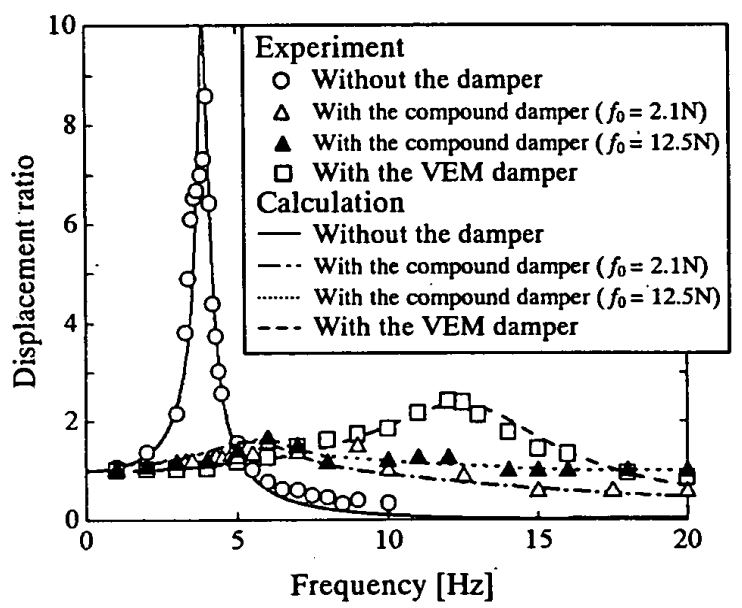

Fig. 11 Frequency responses at the corner of the pipe

した Imperial Valley 地震 (1940)El Centro NS 成分 と $2 \mathrm{~m} / \mathrm{s}^{2}$ に基準化した日本海中部地震(1983)秋田港 NS 成分である。これらの波形を電気油圧式振動台の 上下方向に入力し, 配管屈曲部の相対変位と絶対加速 度を測定した．加速度の測定にはサーボ型加速度計を 用いた。

配管屈曲部の最大変位 $u_{m}$ と最大加速度 $\ddot{y}_{m}$ の実験 結果扔よび計算結果を表 4 に示し, 相対変位応答波形 の実験結果および計算結果を図 12 (a)，（b）に示す. また地震応答時におけるダンパ抵抗力の履歷曲線の計 算值例を図 13 に示す．表 4 および図 12 からわかるよ うに, 配管屈曲部における最大相対変位は, ダンパな しの場合に比べて複合ダンパ $\left(f_{0}=12.5 \mathrm{~N}\right)$ 取付時で 
$1 / 8$ 程度に, 粘弾性ダンパ取付時で $1 / 9$ 程度に低減す る。また, 実験結果と計算結果は似た傾向を示してお り, 計算結果の妥当性が確認された。なお, 複合ダン パの粘弾性材の最適寸法および最適摩擦力は入力加速 度の大きさによって異なるが,これらの最適值につい ては次報において検討する。

$$
\text { 5. ま と め }
$$

ピン支持てこ式変位拡大機構と粘弾性材を用いた複 合ダンパおよび粘弾性ダンパを開発し，その抵抗力特 性を理論解析と実験によって調べた。また，三次元配 管モデルに対する制振効果を周波数応答実験と解析お
よび地震応答実験と解析によって確かめた。おもな結 果は以下のとおりである.

（1）てこ比が 1：2のてこを二段用いることによ って, $\lambda=8.8$ の拡大率が得られる.この二段てこ式 変位拡大機構を用いることにより,てこ先端部の変位 (および速度)は入力変位(および速度)の入倍に拡大 され，その結果弾性体のばね力および減衰力は $\lambda^{2}$ 倍 に, 摩擦力は $\lambda$ 倍に拡大される。

（2）本研究で対象とした $20 \mathrm{~Hz}$ 程度までの周波 数範囲内では, 本粘弾性体は Maxwell モデルと Voigt モデルを並列につないだ四要素モデルで近似で きる.

Table 4 Maxima of the responses at the corner of the pipe

\begin{tabular}{|c|c|c|c|c|c|c|c|c|}
\hline \multirow[t]{3}{*}{ Input wave } & \multicolumn{4}{|c|}{ El Centro (1940) NS $3 \mathrm{~m} / \mathrm{s}^{2}$} & \multicolumn{4}{|c|}{ Akita (1983) NS $2 \mathrm{~m} / \mathrm{s}^{2}$} \\
\hline & \multicolumn{2}{|c|}{ Experiment } & \multicolumn{2}{|c|}{ Calculation } & \multicolumn{2}{|c|}{ Experiment } & \multicolumn{2}{|c|}{ Calculation } \\
\hline & $\begin{array}{c}\text { Disp. } \\
|u|_{m}[\mathrm{~mm}]\end{array}$ & $\begin{array}{c}\text { Accel. } \\
|\ddot{y}|_{m}\left[\mathrm{~m} / \mathrm{s}^{2}\right]\end{array}$ & $\begin{array}{c}\text { Disp. } \\
|u|_{m}[\mathrm{~mm}]\end{array}$ & $\begin{array}{c}\text { Accel. } \\
|\ddot{y}|_{m}\left[\mathrm{~m} / \mathrm{s}^{2}\right]\end{array}$ & $\begin{array}{c}\text { Disp. } \\
|u|_{m}[\mathrm{~mm}]\end{array}$ & $\begin{array}{c}\text { Accel. } \\
\left.|| \ddot{y}\right|_{m}\left[\mathrm{~m} / \mathrm{s}^{2}\right]\end{array}$ & $\begin{array}{c}\text { Disp. } \\
|u|_{m}[\mathrm{~mm}]\end{array}$ & $\begin{array}{c}\text { Accel. } \\
|\ddot{y}|_{m}\left[\mathrm{~m} / \mathrm{s}^{2}\right]\end{array}$ \\
\hline Without the damper & 5.97 & 4.98 & 5.82 & 4.82 & 5.25 & 4.54 & 4.92 & 4.49 \\
\hline With the compound damper $\left(f_{0}=2.1 \mathrm{~N}\right)$ & 0.95 & 2.90 & 1.10 & 2.88 & 1.10 & 2.14 & 1.15 & 2.07 \\
\hline With the compound damper $\left(f_{0}=12.5 \mathrm{~N}\right)$ & 0.85 & 3.14 & 0.78 & 3.06 & 0.68 & 2.09 & 0.53 & 2.03 \\
\hline With the VEM damper & 0.65 & 3.88 & 0.75 & 3.59 & 0.58 & 2.33 & 0.65 & 2.28 \\
\hline
\end{tabular}

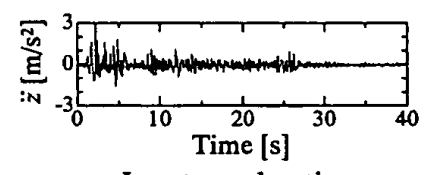

Input acceleration
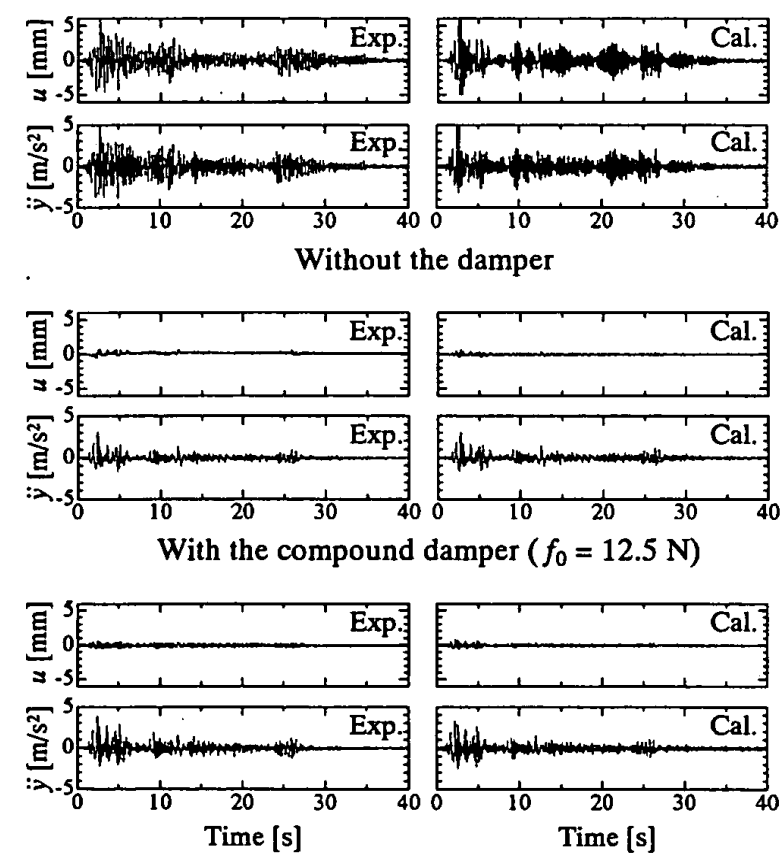

With the VEM damper

(a) El Centro $\mathrm{NS} 3 \mathrm{~m} / \mathrm{s}^{2}$

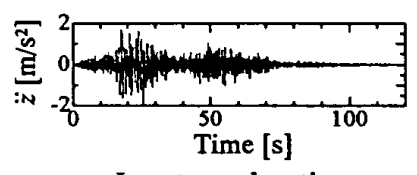

Input acceleration
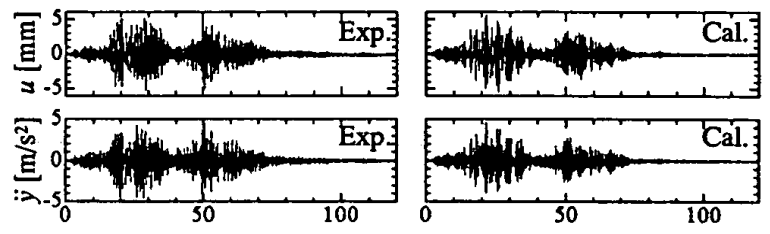

Without the damper
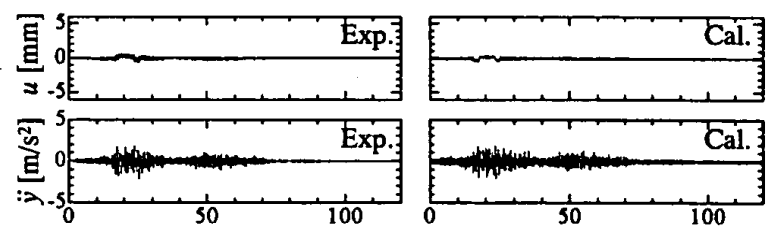

With the compound damper $\left(f_{0}=12.5 \mathrm{~N}\right)$
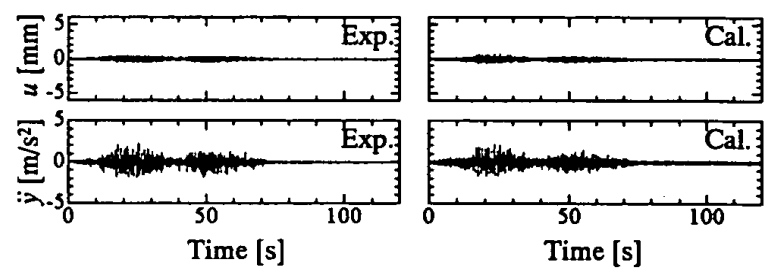

With the VEM damper

(b) Akita $\mathrm{Ns} 2 \mathrm{~m} / \mathrm{s}^{2}$

Fig. 12 Response waves at the corner of the piping 

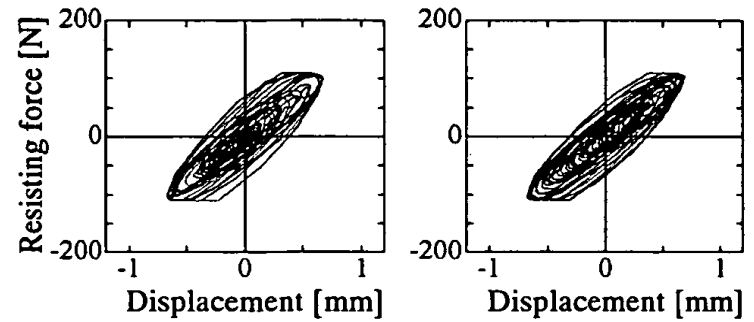

El Centro NS $\left(3 \mathrm{~m} / \mathrm{s}^{2}\right)$

Fig. 13 Hysteresis curves of the compound damper ( $f_{0}$ $=12.5 \mathrm{~N}$ )

（3）三次元配管モデルの周波数応答実験と解析の 結果, 配管屈曲部(ダンパ取付点)の最大たわみは, ダ ンパなしの場合に比べて複合ダンパ $\left(f_{0}=2.1 \mathrm{~N}\right)$ 取付 時で $1 / 6$ 程度に, 粘弾性ダンパ取付時で $1 / 4$ 程度に低 減することがわかった。

（4）三次元配管モデルの地震応答実験と解析の結 果, 配管屈曲部の最大たわみは, ダンパなしの場合に 比べて複合ダンパ $\left(f_{0}=12.5 \mathrm{~N}\right)$ 取付時で $1 / 8$ 程度に, 粘弾性ダンパ取付時で $1 / 9$ 程度に低隇することがわか った.

（5） 周波数応答実験結果と解析結果および地震応 答実験結果と解析結果は，それぞれ似た傾向を示し， 計算值の妥当性が確認された。

終わりに, 粘弾性材料を提供していただいた住友ス リーエム株式会社に深謝する次第である。また本研究 は学術振興会科学研究費補助金 (基礎研究 B) によるこ とを付記する。

\section{付 録}

\section{粘弾性材の耐久試験抵抗力測定実験と同じ実験} 装置を用い, 粘弾性材一枚を金属板で挟んだ試験片を 直接振動台で調和振動させてせん断方向に繰返し変形 を与え, 耐久実験を行った. 繰返し数と各サイクルご との最大抵抗力の関係を図 14 ( a ) に示し, 各繰返し数 における粘弾性材の温度を図 14（b)に示す. 温度は 熱電対を粘弾性材に埋め込んで測定した. 図 14 から わかるように, 最大抵抗力および粘弾性材の温度は 500 サイクル程度でほほ一定になる。

\section{文献}

（1）松岡太一・大亦絢一郎，ピン支持拉大機構を用いた磁気 ダンパの研究, 日本 AEM 学会誌, 9-1 (2001)，605-608.

（2）山下繁生・背戸一登・清水信行，粘弾性材料を用いた動 吸振器による金属バット打撃時におけるしびれ防止，機 論, 57-543, C (1991), 3497-3503.

（3）正木信男・太田雅巳・藤田聡・山家弘行, 高隇衰ゴムの 微少变位振幅領域における減衰特性に関する研究, 機論,

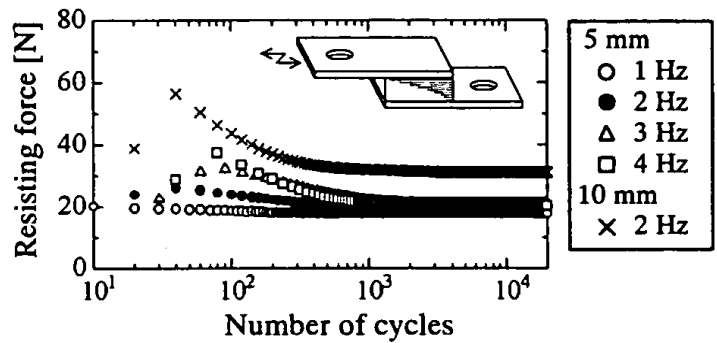

(a) Maximum resisting force

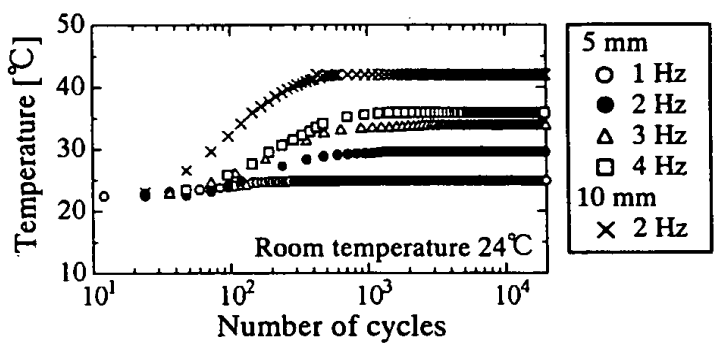

(b) Temperature of the viscoelastic material

Fig. 14 Durability of the viscoelastic material

63-611, C (1997), 2243-2249.

（4）曽田五月也・高橋雄司，ランダム加力による粘弾性ダン パーの振動数依存性の定量化, 日本建築学会構造系論文 集, 498 号 (1997), 43-49.

（5）藤田聡・ほか 6 名, 高減衰ゴムダンパを用いた高層建物 の制振に関する研究(第 3 報, ダンパの温度依存性と耐久 性に関する考察)，機論，64-617, C (1998)，86-91.

（6）神保浩之-見坐地一人-柴田耕一, 周波数, 変位振幅依存 型非線形振動に対する履歴系解析手法の研究(履歷則の 改良と防振ゴムの振動応答), 機論, 63-630, C (1999), 441-448.

（7）正木信男・田村和夫，制振装置用大型多段積層ゴムの剛 性解析, 機論, 65-631, C (1999), 902-909.

（8）佐藤美洋, 振動堿衰により内部発熱する粘弾性体の定常 応答解析 (解析法と固定温度境界の二次元問題)，機論， 66-643, C (2000), 700-707.

（9）佐藤美洋・・防振ゴムを用いた動吸振器の設計法, 機論, 66-645, C (2000), 1544-1550.

（10）池田富士雄・川田誠一・小口俊樹, 分数階微分アクティ ブマスタンパによる柔軟構造物の振動制御, 機論, 67-661, C (2001), 2798-2805.

（11）寺本道彦・笠井和彦，粘弾性・弾塑性体直列結合ダンパ 一の制振効果に関する研究(その 1 力学的挙動につい て), 日本建築学会大会学術講演会梗概集, 21488(1999), 975-976.

（12）矢澤倰介 - 笠井和彦 - 寺本道彦 - 伊藤秀樹，粘弾性・弾 塑性体直列結合ダンパーの制振効果に関する研究(その 3 動的載荷実験), 日本建築学会大会学術講演梗概集, $21477(2000), 953-954$.

（13）清水信行・大和田浩史, 粘弾性動吸振器の最適調整に関 する研究(分数階フォークトモデルによる解析)，機論， 64-628, C (1998), 4599-4604.

（14）清水信行・張衛, 分数階微分オペレータで記述される粘 弾性体の有限要素解析 (3 次元の構成方程式と有限要素方 程式の定式化), 機論, 66-647, C (2000)，2135-2142. 